Volume 6 Issue 2, June 2019

\title{
Analysis Of Nullification And Cancellation Of Notary Deed In The Perspective Of Act No. 2 Of 2014 On Notary
}

\author{
Devi Nindy Lestari ${ }^{1}$ and Latifah Hanim ${ }^{2}$
}

Abstract. The purpose of this study was to: 1) to assess and analyze the implementation of nullification and cancellation Deed in the perspective of Act No. 2 of 2014 concerning Notary, 2) to assess the implications of the law, and 3) to identify and analyze the barriers and solutions regarding nullification and cancellation of the Deed. The data used in this study are primary data, secondary data, and data that can uphold tertiary study, which was then analyzed by descriptive analytic method.

Based on the results of data analysis can be concluded that: 1) notarial deed nullification and cancellation can occur for non-fulfillment of objective conditions; terpenuhiya not subjective terms of a contract, and can be canceled by the parties themselves. 2) The legal implications as a result of nullification and cancellation Deed is a notarial deed which can be canceled by the parties themselves, the notarial deed null and void, the notarial deed only has the strength of evidence deed under hand. 3) Obstacles and solutions that not all Notaries know and understand the terms of authenticity, validity and causes nullification and cancellation of a notarial deed. Notaries who do not understand the need to study the causes nullification and cancellation deed refers mainly to provisions UUJN and the Civil Code.

Keywords: Deed; Nullification and Cancellation.

\section{Introduction}

Notaries are public officials appointed by the Government to assist the public in making agreements that exist or arise in the community. The necessity of written agreements made before a notary is to ensure legal certainty for the parties to the agreement. The need for written evidence in the form of an authentic deed is increasing in line with increasing demand for legal certainty in a variety of economic and social relations, both at the national, regional, and global. Ie the end product Notary authentic deed.

Authentic deeds as proof of the strongest and most have an important role in any legal relations in society. So important function of the notarial deed are, therefore, to avoid not the validity of a certificate, the institution Notary regulated under Regulation Notary for subsequent written (PJN), which has now been replaced by Act No. 2 of 2014 on Amendment oF Act No. 30 of 2004 concerning Notary. And hereinafter called Notary law abbreviated UUJN.

Notary authority as referred to in Article 15 UUJN to his profession as an authentic deed is accompanied by the development community needs very rapid and dynamic has increased the intensity and complexity of the legal relationship that would require certainty, order, and legal protection that core truth and justice. Understand the terms of authenticity and causes nullification of a notarial deed, it is very important to avoid preventive juridical notary deed defect that could result in loss of authenticity and the cancellation of the notarial deed, as well as facilitate any notary to make the deeds of notary in accordance with the Notary law laws and other legal rules applicable. ${ }^{3}$

Notary in making a notarial deed shall be in accordance with the provisions stipulated in the UUJN, if it does not meet one or more of these elements then a notary deed resulted

\footnotetext{
${ }^{1}$ Students of Master of Notarial Law UNISSULA E-mail: devinindylestari@gmail.com

2 Lecturer Master of Notary UNISSULA, Semarang

3 Pieter E. Latumeten, 2011, Cacat Yuridis Akta Notaris Dalam Peristiwa Hukum Konkrit dan Implikasi Hukumnya, Tuma Press, Jakarta, p.31.
} 
in nullification or cancellation of a notary deed. It shows how a notary public accountability in carrying out the authority and obligations. In fact there is clearly a rogue notary. But the notary who became the target of extortion is also there. In practice many notaries who commit irregularities or errors in making notarization, either due to dishonesty notary itself or the parties facing.

In order for the deed he had made a complete weight of the evidence and have validity. Notary not merely as a clerk, but the notary will also need to assess whether they want the applicant to be stated in an authentic deed is not contrary to UUJN and other applicable laws. Obligation to know and understand the terms of authenticity, validity and causes nullification and cancellation of a notary deed is essential to avoid any legal defects that can result in nullification and pembatalanya notarization, where it would be detrimental to the interests of society, especially those who concerned. ${ }^{4}$

Based on the background mentioned above, the authors are interested in conducting research with the title: "Analysis of nullification and cancellation of Notary Deed in the Perspective of Act No. 2 of 2014 On Notary".

\section{Research methods}

The research method was used in empirical research. Adopting legislation, learning materials primary and secondary law. Mechanical collection of legal materials through interviews and literature study and analysis techniques in the analysis of legal material deduction.

\section{Results and Discussion}

\subsection{Implementation Deed Nullification And Cancellation In The Perspective of Act No. 2 of 2014}

Indonesian dictionary mentions various meanings of the word "cancel". Among them is meaningful not valid or invalid. As in the phrase: "the agreement was declared void". Canceling means declared void (invalid), as in the phrase: "they canceled the agreement ever agreed upon". Therefore, cancellation is a process, method, action to cancel. ${ }^{5}$

In contract law, null and void (nietig) is the term for agreements that do not qualify objective (certain things and causes that kosher). Whereas, for the purpose of the agreement can be canceled are not eligible subjective (and prowess agreement). Unlike the situation that can be canceled, null and void state does not require a request from the parties. However, according to R. Subekti, if an agreement is not eligible objective, but there are sued, the judge is obliged because of his position, said there never was an agreement or engagement.

The difference between the nullification and cancellation lies in whether or not the request of a party ${ }^{6}$.

Legal regulations related to the cancellation and nullification of Notary deed contained in the Law on Notary and the Civil Code are as follows: ${ }^{7}$

- Notary law

In Notary law mentioned there are two possibilities if the deed contains a legal flaw, namely the deed otherwise have the strength of evidence as the deed under the hand,

\footnotetext{
4 Idris Aly Fahmi, 2013, Degradasi Kekuatan Pembuktian dan Pembatalan Akta Notaris Menurut Pasal 84 Undang-Undang Nomor 30 Tahun 2004 Tentang Jabatan Notaris, Arena Hukum, Nomor 2 Volume 6,p.220.

5 http://kbbi.web.id/, Accessed on March 20, 2019.

6 Habib Adjie, 2017, Kebatalan dan Pembatalan Akta Notaris, Refika Aditama, Bandung, p. 63.

7 http: // jiptummpp-gdl-tasyamoedy-47509-3-babiii, Accessed on March 21, 2019.
} 
and the deed null and void. Notary deed has the strength of evidence as the deed under the hand if it is mentioned explicitly in the relevant chapters. If not mentioned explicitly in the article in question, it is included as a deed null and void because it did not meet the elements laid down by law.

- Code of Civil law

The reasons for judicial cancellation of a notary deed is generally outside of the rules set out in the Notary Act that resulted in the cancellation and nullification notarial deed is essentially the same as the reasons for cancellation of the agreement in the Civil Code juridical.

Under Article 1320 Book of Law - Civil Code states that there are four terms, if the first condition (a deal for those who make it) and second (ably in terms of legal actions) which is a condition of the subjective is not met then the certificate can be canceled, and if the requirements to three (certain things) and fourth (causes kosher) which is an objective requirement is not met then the certificate becomes null and void.

Implementation of nullification and cancellation of a notarial deed is rare in practice. The cancellation is usually carried out by the parties themselves with the accord and usually their disputes arise in the contents of the deed and sued in court. The reasons for the cancellation of the visits in the Civil Code, which in Article 1320 of the 2 requirements subjectively agreed and capably, ably example of Directors representing the PT must be approved by all of the Board of Commissioners, if only any one is approved then it is incompetent. Then in terms of a deal, appear at the time the deed was made, if there is an element of deception, lies, mistakes, then these things will result in the cancellation of the deed. ${ }^{8}$ Implementation of nullification and cancellation namely for violating the terms of formal, material or outwardly notarization, which have been made pursuant to a deed which is hinted at in UUJN. Another reason that a notarial deed which can be canceled because of the angle facing ineligible subjectively validity of the agreement as stated in Article 1320 of the Civil Code, namely: 1) those agreements which bind himself, and 2) an agreement to make an engagement. Then, because the material requirements are not met or are not eligible objective validity of the agreement as mentioned in Article 1320 of the Civil Code, namely: 1) a specific subject matter, and 2) a cause that is not forbidden. ${ }^{9}$ Implementation of nullification and cancellation of a notary deed on deed Partij, both agreed to cancel the notarial deed of the cancellation will also depend on the clauses the agreement that outlines the terms of the cancellation of the agreement, if the parties / applicant agreed to cancel the automatic certificate has been canceled, but much better must notify the notary if you want to revoke the certificate and certificate revocation notary make more certain that there is no attachment. While relaas deed itself could undo it, better even told the notary to make a deed of revocation, the reasons for nullification and cancellation of a notary deed depends on the agreement of the parties, and usually violate the provisions of law. ${ }^{10}$

\subsection{Against Legal Implications Of Nullification And Cancellation Og Notary Deed}

Legal implications regarding nullification and cancellation of a notarial deed pursuant to Act No. 2 of 2014 concerning Notary that resulted in deed only has the strength of evidence as the deed under the hand and null and void, to determine the notary deed that has the strength of evidence as the deed under the hand can be seen and is determined from the

\footnotetext{
${ }^{8}$ Interview with Idris Abbas, Notary and PPAT Cirebon, on 24 April 2019.

${ }^{9}$ Interview with Indra Cahyadi, Notary and PPAT Cirebon, on 24 April 2019.

${ }^{10}$ Interview with Solichin, Notary and PPAT Cirebon, on 24 April 2019.
} 
contents (in) certain articles that affirm directly if Notary offense, the deed in question included a deed that has the strength of evidence as the deed under hand. If not mentioned explicitly in the article in question as a deed that has the strength of evidence as the deed under the hand, then the other article that violate categorized in accordance with Article 84 UUJN included in the deed null and void. ${ }^{11}$

The term certificate that has the strength of evidence as a deed under hand deals with a probative value of evidence. Deed under the hands have the strength of evidence all the contents and signatures contained in it is recognized by the parties. If one of the parties deny it, the value of the evidence submitted to the judge. ${ }^{12}$

If a notary deed does not satisfy the subjective elements that may be canceled, and if the certificate does not meet the elements of the treaty objective in the notarial deed may be null and void. Void is a civil sanction against a legal act which causes nullification flawed juridical (cause nullification), in the form of legal acts which do not have legal consequences since the act of the law or legal actions that are not applicable since the deed was signed and the legal action called in deed deemed never happened. If re-look at the qualifications specified KUHPerdata relevant notarial deed are null and void, as provided for in Article 1320, 1335, 1336, and 1337 of the Civil Code, the use of the term "null and void" for the notarial deed for violating the provisions stipulated in the provisions Article 84 UUJN be exact. This is because the provisions are classified as a notarial deed restrictions are null and void under Article 84 UUJN none of which contain elements of a violation of the object of the agreement, as well as a violation of the lawful because, as stipulated in the Civil Code. ${ }^{13}$

The legal implications of the nullification and cancellation Deed is irrevocable and void, may be canceled because it is not subjective qualify an agreement that is capable of doing a legal act and agreed to those who make it. While void retroactive meaning that never existed, null and void concerning the object, for example, stolen goods, it is not allowed because it violates the law. ${ }^{14}$ Ie legal implications canceled notarial deed, notarization can be canceled, and the notary deed null and void. 1) which can be canceled notary deed is the deed that was canceled by the applicant themselves by notarial deed on grounds which are known by the applicant alone or under a court decision on the grounds that the verdict in the legal considerations are concerned. Notaries can only make a deed of cancellation at the discretion of the applicant itself, 2) notarial deed which can be canceled since applicant not eligible subjective validity of the agreement that is agreed and capable, notarization in qualifying to be canceled will remain binding upon the applicant concerned as long as nobody filed cancellation to the Court, 3) the notary deed null and void because the material requirements are not met or are not eligible objective validity of the agreement that is a specific issue and a cause that is kosher. ${ }^{15}$ Legal implication is null and void, because the object is not clear or does not exist and can be canceled because not agree and ably set forth in Article 1320 of the Civil Code. ${ }^{16}$

\footnotetext{
${ }^{11}$ Habib Adjie, nullification and cancellation Deed, op.cit, p. 66.

${ }^{12}$ Habib Adjie, 2015, the Indonesian Notary Law Thematic Interpretation Based on Law No. 2 of 2014 on the Amendment of Act No. 30 of 2004 concerning Notary, Refika Aditama, Bandung, p. 58.

13 Aly Fahmi Idris, 2013, the Strength Degradation Verification and Cancellation Deed Pursuant to Article 84 of Law No. 30 of 2004 concerning Notary, Legal Clinics, Number 2 Volume 6.

${ }^{14}$ Interview with Idris Abbas, Notary and PPAT Cirebon, on 24 April 2019.

15 Interview with Indra Cahyadi, Notary and PPAT Cirebon, on 24 April 2019.

${ }^{16}$ Interview with Solichin, Notary and PPAT Cirebon, on 24 April 2019.
} 
Volume 6 Issue 2, June 2019

\subsection{Obstacles And Solutions Of Nullification And Cancellation Of Notary Deed In The Perspective Of Act No. 2 of 2014 on Notary}

Obstacles and solutions nullification and cancellation of the notarial deed is as follows:

- Not all Notaries in running position with respect to the deed, know and understand the terms of authenticity, validity and causes nullification and cancellation of a notarial deed. Especially for those who are new notary, so that notaries who do not understand the need to study the causes nullification and cancellation of such deed refers mainly to provisions UUJN and the Civil Code, and is expected to consult the senior notary. In making the deed to the awareness of the legal, moral, ethical. Notary materially supposed to know the rules that apply in the manufacture of a notarial deed to anticipate all the legal risks that occur in society, particularly in casting an authentic deed made by and before a notary.

- Notary in running his negligent, careless, and less scrupulous in making authentic act, notary must satisfy the principle of accuracy and prudence. It notary should be more cautious and careful in order not negligent in performing his rank, who represent the public interest, so that the will of the parties can be stated in the deed and not against the law. ${ }^{17}$

- The parties affected by the lure of the price of the deed with, and the party in default abused them, giving rise to the dispute and filed a lawsuit that resulted in deed is canceled, the solution is the applicant not be affected by the price of the deed of cost and must carry out under the terms of the agreement. ${ }^{18}$

- In practice there is usually a Notary rogue who does not follow the rule of law and does not promote the rule of law, is not neutral and independent, for example in terms of the deed permbuatan not read the deed before the parties and other formal requirements infringed deed by Notary. If it is not read by the Notary should be a prior agreement between the parties that the certificate does not need to be read, and at the end of the deed of the applicant write a sentence that requires that the deed was not read because applicant read yourself, know and understand the contents of the deed. As well as in this case gives legal advice to the parties who will make an authentic deed, so that the deed could serve as a perfect proof. ${ }^{19}$

- Not all applicant behave honest and open, do not have good faith to the Notary. The parties to Notary should always help Notary to express the real thing based on good faith and honesty, so that the figure is perfectly in accordance with the applicable law, so as not to harm any party.

- Barriers if applicant want to cancel the deed with a deed pembatalanya is the applicant difficult to come back to the notary's office, did not need their deed has also been canceled, but better accompanied by certificates for cancellation, in order to have proof that binding. ${ }^{20}$

\section{Closing}

\subsection{Conclusion}

Based on the description above, the authors concluded that:

- Implementation Deed nullification and cancellation in the Perspective of Act No. 2 of 2014 is in the law of treaties, null and void (nietig) is the term for agreements that do

\footnotetext{
${ }^{17}$ Interview with Idris Abbas, Notary and PPAT Cirebon, on 24 April 2019.

${ }^{18}$ Ibid.

${ }^{19}$ Interview with Indra Cahyadi, Notary and PPAT Cirebon, on 24 April 2019.

${ }^{20}$ Interview with Solichin, Notary and PPAT Cirebon, on 24 April 2019.
} 
not qualify objective (certain things and causes that kosher). While not eligible to be canceled subjective (and prowess agreement). The difference between the nullification and cancellation lies in whether or not the request of a party.Nullification and cancellation of a notary deed can occur for several reasons not the objective conditions are met; ineligible subjective of a treaty,

- Legal Implications of the nullification and cancellation Deed is a notarial deed which can be canceled, null and void notary deed, deed notary deed only has the strength of evidence under the hand

- Obstacles and Solutions of nullification and cancellation Deed in the Perspective of Act No. 2 of 2014 concerning Notary ie barriers and solutions that not all Notaries know and understand the terms of authenticity, validity and causes nullification and cancellation of a notarial deed. Notaries who do not understand the need to study the causes nullification and cancellation deed refers mainly to provisions UUJN and the Civil Code, notaries negligent and careless run jabatanya so it is expected the notary must be careful, in practice there is usually a notary rogue who does not follow the rules law, is not neutral and independent, not all applicant behave honest and open, do not have good faith to the Notary.

\subsection{Suggestion}

To complete this study, the authors suggest the following:

- for Notary

Notaries perform their duties should make an authentic deed, should be more careful in making such deed and the need for awareness about the legal, moral, ethical. Notary materially supposed to know the rules that apply in the manufacture of a notarial deed to anticipate all the legal risks that occur in society, particularly in casting an authentic deed made by and before a notary.

- For Parties

That the parties are facing a notary should always help the notary to express the real thing based on good faith and honesty, so that the figure is perfectly in accordance with the applicable law, so as not to harm any party.

\section{Bibliography}

[1] Habib Adjie, 2015, Penafsiran Tematik Hukum Notaris Indonesia Berdasarkan Undang-Undang Nomor 2 Tahun 2014 Tentang Perubahan Atas Undang-Undang Nomor 30 Tahun 2004 Tentang Jabatan Notaris, Refika Aditama, Bandung.

[2] Habib Adjie, 2017, Kebatalan dan Pembatalan Akta Notaris, Refika Aditama, Bandung.

[3] Pieter E. Latumeten, 2011, Cacat Yuridis Akta Notaris Dalam Peristiwa Hukum Konkrit dan Implikasi Hukumnya, Tuma Press, Jakarta.

[4] Constitution of the State Repubik Indonesia of 1945

[5] Civil Code / BW (Burgerlijke wetboek).

[6] Act No. 30 of 2004 concerning Notary

[7] Act No. 2 of 2014 concerning amendments to the Act No. 30 of 2004 concerning Notary

[8] Notary Code

[9] Idris Aly Fahmi, 2013, Degradasi Kekuatan Pembuktian dan Pembatalan Akta Notaris Menurut Pasal 84 Undang-Undang Nomor 30 Tahun 2004 Tentang Jabatan Notaris, Arena Hukum, Nomor 2 Volume 6.

[10] http://kbbi.web.id/, Accessed on March 20, 2019.

[11] http: // jiptummpp-gdl-tasyamoedy-47509-3-babiii, Accessed on March 21, 2019. 